\title{
Government Innovation of Kulon Progo "Bela-Beli" Programme
}

\author{
Teguh Yuwono*1, Warsito $^{2}$, Dzunuwanus Ghulam Manar ${ }^{2}$ \\ ${ }^{1}$ Graduate Programe of Political Science, Universitas Diponegoro, Semarang \\ ${ }^{2}$ Department of Governance Studies, Universitas Diponegoro, Semarang
}

\begin{abstract}
Innovation can be found in many local government of Indonesia. However, innovation based on ideology only found in Kulon Progo Regency of Yogyakarta Special Area. Under administration of Hasto Wardoyo, the regent, innovation goes to many areas and brings many benefits for both people and government. It ignited economics development, public and private participation, as well as government transformation. It is important to understand the innovation process since it comes from ideological aspect that is different from any innovation ever.
\end{abstract}

Keywords: Innovation, Ideology, Government

\section{Introduction}

There are empirical and theoretical backgrounds that are significant as an entry point to research about innovation in Kulon Progo regency. On the empirical aspects, there are specific innovation that different to other areas, ideology-based innovation, priority on protecting local and national interest, people approval and support toward the innovation, and local valuebased innovation. A specific innovation refers to innovation that executely different from other local governments [1]. There is a value that make people believe can turn their situation much better. Ideologybased innovation comes from idea that national ideology as initiated by Soekarno, the first president of the Republic of Indonesia called Tri Sakti (three sacred) is foundation of the innovation. Tri Sakti is principal that become an ideology consists of political sovereignty, economics self-sufficiency, and cultural independence. The Last two are basic for innovation in Kulon Progo. Protection of local and national interest is based on Tri Sakti so that people of Kulon Progo can have sense of belonging and pride towards local economics resources and another local commodities. Futhermore, there are huge support towards the innovation as resulted and reflected during second local election in 2017, the incumbent, Hasto Wardoyo had $90 \%$ turnout. He started the innovation in 2013 after a year in the office, and the turnout described strong support from the people. Finally, it is a local value-based innovation since many local government also have some innovation programme, but mostly came from "western theories". Idea based on transparency and openness, good governance, as well as democracy is perceived as western ideas. However, in Kulon Progo, innovation is held by using own national ideology that comes from Tri Sakti of Soekarno that originally local ideas.

On the other hand, theoritical background provides argument importance of local innovation based on the ideology. First, it is use national and local ideology based on Tri Sakti of Soekarno rather than using western theories, such as good governance, democracy, transparency, open government, etc. [2, 3, 4]. Western domination theories were not operated in the innovation. Second, ideology-based innovation still small and less paid academic attention within governance studies. It is because predominantly innovation and best practice of the government are inspired and influenced by success story on developed countries. Using this framework, it is important to identify and describe local best practice and experience that based on local values for the future reference. Therefore, it will make a significant contribution for the extention of governance studies in Indonesia. Finally, most of theory or studies on innovation are focused on output, not on process. Perspective to reveals on process of innovation is important in order to reveal succes story of innovation [5].

Innovation is a process within government in order to come to new situation that completely different. It can be operated into 4 stages, starting from innovation capability, innovation activity, wider sector condition for innovation, and impact on performance [6]. Innovation capability refers to situation that enabling process and output innovation works successfully. It covers leadership and culture, innovation management and organizational ability. On the developed countries, innovation capability comes from different actors, conservely, among developing countries, it comes from the leader. It is happen because in developing countires,

\footnotetext{
*Corresponding author: teguhyuwonos@gmail.com
} 
leader has access, domination, as well as authority to initiate change and innovation [3,7].

Second stages, innovation activity is activity flows so that innovation works appropriately. It consists of four processes, from generating ideas, selecting ideas, implementing ideas, and diffusing ideas [8]. Generating ideas is activity where ideas for change and innovation are formed, either from individual, group, or leader. Selecting ideas is choosing one among the many, an idea that appropriate to be executed and continued into implementation. After all, ideas might be diffuse to any relevant agencies or public for further development and improvement.

Wider sector condition for innovation refers to factors that enabling government innovation works smoothly. It consists of leadership and culture, autonomous, incentives, and enablers, the enabling factor. The later might be the people or parties that enabling innovation works [7]. Impact on performance is result from innovation process, such as organizational performance improvement, service improvement, as well as performance improvement. In sum, these stages reflects that innovation is procedural and gradual, backed up by actors, resources, and enablers so that it can be identified, measurized, and produce intended result.

The paper will discuss several issues regarding innovation of local government of Kulon Progo known as Bela Beli Kulon Progo programme, but mostly stand on process of innovation and its policies since the beginning up to now.

\section{Methodology}

This paper is derived from a research result conducting in Kulon Progo using multi-method type of research namely qualitative research and survey. The multi method type of research is used in order to get comprehensive findings related to innovation Bela Beli programme.

\section{Discussion}

The major scenario of innovation is Bela Beli Kulon Progo, which mean is a campaign initiated by the regent to people of Kulon Progo in order to defend, stand, and consume local product as strategy to deal with globalization and economics challenge. This value in accordance with Tri Sakti ideology, mainly economics self-sufficiency. According to the regent, this is the key for another two. Once we can establish economics independence, there will be easier to gain political and cultural autonomy.

Having experience as a student short programme of in vitro fertilisation in Japan and Korea during his service as a medical doctor, Hasto Wardoyo came to an idea that ideology is important for human being. Even, it can deal and beat technology. He realized that in order to compete into advance technology and economics is very difficult regarding many obstacles faced by most of the people. He choosen economics as a primary goal of innovation because he believed that economics sector can attract and force any activities relate to innovation. It was started on March 25, 2013 in alun-alun/big square of Wates he declared Bela Beli Kulon Progo movement. No paper, no (authentic) policy, no formal document were needed. By asking the people to stand together, defend, and consume local product, he emphasized that it was the only way to survive and compete into economics challenge. If they refused, there will be a big lost because they can not maintain and sustain economics progress. It means that their life will be back in suffer, even worse.

There are several important policy innovations regarding to Bela Beli Kulon Progo Programme which are initially developed by Regent Hasto Wardoyo, as following explanation. Firstly, a policy which asked the local drinking water company (PDAM) of Kulonprogo to produce and sell drinking water in a glass or bottle water. The PDAM does not only produce clean water for domestic household purpose, but also must be able to produce water bottle that is sell widely. This local water bottle product is the called AirKu, an abbreviation for Air Kulon Progo (the water of Kulon Progo). This policy is well implemented as seen in fact that local consumption demand for AirKu is increasing and seems not able to fulfill all public needs. In return, it can contribute significantly to the local revenue.

Secondly, it is obligated to local civil servants of Kulon Progo regency to buy local rice product. This policy is designed to assist and defend local farmers so that they are able to survive in a market mechanism. By buying rice local product of Kulon Progo, the government supports a process of enhancing local farmers' welfare. Using the group of farmers called GAPOKTAN (Gabungan Kelompok Tani) an association of farmer groups of Kulon Progo, he also invite BULOG (Badan Urusan Logistik) National Agency of Logistic to buy local rice and then store or delivery as necessary as a logistic reverse. With this policy, he can empower farmer by providing market.

Thirdly, a policy of asking local students and civil servants of Kulon Progo Regency to wear local batik clothes namely batik Gebleg Renteng. Gebleg is local food which is used as a symbol of local power to respond to global market. By wearing and buying local batik products are for sure able to assist local batik entrepreneurs. At least, local entrepreneurs may improve their economy and businesses. Fourthly, a policy demand local building entrepreneur to use local product such as local stone and sands. This is designed to empower local building farmers who product local stones and sands to supply domestic needs for local infrastructure development. Local building farmers are happy and endorse this policy enthusiastically. Fifthly, a policy to promote local product when a cheap market or 
food packets are implemented in Kulon Progo Regency. By this policy local people and farmers are beneficial and having opportunity to improve their family economy. Using local products also increase local prides of Kulon Progo Regency.

Sixth, a policy of promoting medium scale entrepreneurships by collaboration between local entrepreneurs and local minimarket called Toko Milik Rakyat/Tomira (minimarket owned by the people). Tomira is intended to be a market of all local products of Kulon Progo. A government license of establishing minimarket such as Alfamart or Indomart is designed limited in order to protect local economy. The people economics activities may exists if the local government taking action by limiting modern minimarket such as Alfamart and Indomart. To compete with networked minimarkets is very difficult if the government does not rule and protect local people economy. This policy is well implemented under the Bela Beli Kulon Progo Programme.

Finally, promoting local unique product called gula semut (ant red sugar) of Kulon Progo is a strategic policy to increase economic capacity. Ant red sugar is very unique and only produced by Kulon Progo. This uniqueness is improving bargain power of farmer in global competition market because this product is only produced in Kulon Progo Regency, global market may ask this important product. There are several programme that can not be describe, such as local tea and coffe of Surolo, Bedah Rumah/improving housing programme for the needy, hospital without classes, the flagship fruit, such as durian Menoreh and many more. It reflects the credo of the regent in the beginning of the programme, starts small, act now, think big. After 4 years of ignition moment, they reaps lots of innovative products as result of collaboration among government, people and relevant private sectors.

Kulon Progo also sees another opportunity in environmental strength. Having diverse geographical situation from mountainous resources to the agricultural productions, the Program Bela Beli Kulonprogo under the principle of Tri Sakti will not only be implemented in the economic matters, but it can also extend to the local environment potential. The baby-step of Regent efforts to explore environmental potential has been started through urging the residents to have self-made natural resources in order to sell finished goods instead of raw materials and utilize it for local infrastructure. The strong prospect area of environment in Kulon Progo is Menoreh Mountains region which has abundant natural andesite rocks collected by residents, but it has not been much developed. In agricultural sector, the Regent invited Gabungan Kelompok Tani (Gapoktan) or Farmer Association not to sell their rice in the form of grain. Further, this program boosts the food security in Kulon Progo.
Innovations of Bela Beli Kulon Progo Programme are unique and different from many other innovations in public sector. It is unique and different because there are several reasons for these uniqueness and differences. Firstly, the importance of ideology. Ideology is the first key success of innovation in Kulon Progo Regency. Trust on ideology called Tri Sakti Bung Karo has led the regent to develop unique innovation called Program Bela Beli Kulon Progo. Interview with Hasto Wardoyo reveals that ideology is the first thing to embed in his innovation program and development. Tri Sakti ideology, which strongly believe on self-power and resources are significant element of reform or innovation. By strongly embedded ideology, bureaucracy and people of Kulon Progo Regency have positive energy and motivation to develop their own local government.

Secondly, leader's passion and motivation of Regent Hasto Wardoyo. It is a matter of fact that passion, motivation and high confidence of the leader provide more energy, enthusiasm, passions of the people to manage innovation. Regent Hasto Wardoyo leadership is significant to make sure the innovation idea and implementation are implemented well as designed. Since implementation is a key important success, direct control and supervision from the Regent as a leader is pivotal. Interviews with three important bureaucrats from Kulon Progo Regency reveal that the regent's leadership is very strong to influence and make innovation take a place very well. They feel more enthusiastic and positive response to innovation programs of Bela Beli Kulon Progo because of the Regent direct supervision and monitoring during innovation process and implementation. Thirdly, bureaucratic's trust and supports. Bureaucratic trust and supports are also relevant to make sure that the innovations of Program Bela Beli Kulon Progo run appropriately. Local government bureaucracy of Kulon Progo Regency has a high trust and supports to the Regent not only because of his command but also bureaucrats' need to innovate and enhance local prides of Kulon Progo. Interviews with a second rank bureaucrat of the regency show that bureaucracy is willing and happy to succeed the Regent's policy proposal on the Program Bela Beli Kulonprogo.

Fourth, private sector trust and supports. These supports indicated by their willingness to involve in innovation processes designed by the Regent. Private sectors especially local entrepreneurs and local building or infrastructure sector people endorse Program Bela Beli by providing all products needed by local people. They are very happy and willing to join continuously the designed programme. Last but not the least, society trust and supports. This trust is indicated by high index of trust on ideology initiated by the Regent (shown by the result of this survey). Quantitative calculation on the index of trust and ideology is 3.04 of 4 (4 scale basis). 
This means that $76.10 \%$ people are highly trust to ideology of Tri Sakti as endorsed by the Regent. Moreover, the index of society participation is also high namely 3.14 of 4 ( 4 scale basis). This figure tells that people of Kulon Progo is participative and supportive the Program. The people believes that success of Program Bela Beli enhance local prides of Kulon Progo Regency.

\section{Conclusion}

Bela Beli Kulon Progo is a distinctive innovation, since it is based on ideology, not an existing best practices or inspires by other areas. It is firm and robust in providing evidence that local and national ideology might serve as the ideas of innovation. Supported by a good leadership as demonstrated by the Regent Hasto Wardoyo, it drives many actors and people to establish innovation in order to deal with economics and global challenge. Within this framework, ideology-based innovation goes over policies and regulations. It is a movement to struggle for self-reliant and economics independent.

\section{References}

1. T. Yuwono, "Importance of Context in Good Governance Innovation in Indonesia". Paper presented on International Seminar of ADIPSIUNITAS Palembang, 25-26 Januari 2017 (2017).

2. M. S. Grindle, "Going Local: Decentralization, Democratization, and the Promise of Good Governance", Princeton University Press, Oxfordshire (2007).

3. A. Kay, "The Dynamics of Public Policy: Theory and Evidence", Edward Elgar Publishing Limited, Cheltenham, (2006).

4. M. Chibba, "Governance and Development: The Current Role of Theory, Policy and Practice." World Economics, Vol. 10 (2) April-June pp 79-108 (2009).

5. M. S. Grindle, "Good Governance: The Inflation of an Idea", Harvard Kennedy School, Massachusetts (2010).

6. O. Serrat, "Innovation in the Public Sector", Asian Development Bank. Washington D.C., (2012)

7. H. S. Sumarto, "Inovasi, Partisipasi dan Good Governance: 20 Prakarsa Inovatif dan Partisipatif di Indonesia”, Buku Obor, Jakarta (2009).

8. G. Dudley and J. Richardson, "Why Does Policy Change?: Lessons from British Transport Policy, 1945-1999”, Routledge, New York (2000). 